\title{
Outbreaks associated to large open air festivals, including music festivals, 1980 to 2012
}

E Botelho-Nevers ${ }^{1}$, P Gautret (philippe.gautret@club-internet.fr) ${ }^{1}$

1. Institut Hospitalo-Universitaire Méditerranée Infection, Université Aix-Marseille, Faculté de Médecine, Marseille, France

Citation style for this article:

Botelho-Nevers E, Gautret P. Outbreaks associated to large open air festivals, including music festivals, 1980 to 2012. Euro Surveill. 2013;18(11):pii=20426.

Available online: http://www.eurosurveillance.org/ViewArticle.aspx?Articleld=20426

In the minds of many, large scale open air festivals have become associated with spring and summer, attracting many people, and in the case of music festivals, thousands of music fans. These festivals share the usual health risks associated with large mass gatherings, including transmission of communicable diseases and risk of outbreaks. Large scale open air festivals have however specific characteristics, including outdoor settings, on-site housing and food supply and the generally young age of the participants. Outbreaks at large scale open air festivals have been caused by Cryptosporium parvum, Campylobacter spp., Escherichia coli, Salmonella enterica, Shigella sonnei, Staphylococcus aureus, hepatitis A virus, influenza virus, measles virus, mumps virus and norovirus. Faecal-oral and respiratory transmissions of pathogens result from non-compliance with hygiene rules, inadequate sanitation and insufficient vaccination coverage. Sexual transmission of infectious diseases may also occur and is likely to be underestimated and underreported. Enhanced surveillance during and after festivals is essential. Preventive measures such as immunisations of participants and advice on-site and via social networks should be considered to reduce outbreaks at these large scale open air festivals.

\section{Introduction}

Mass gathering (MG) medicine is an emerging specialty [1] that includes effective strategies and planning to address health security and risks associated with MGs. The number of attendees that classifies an event as a 'mass gathering' is wholly arbitrary. Definitions vary greatly, with some sources specifying any gathering to be a MG when more than 1,000 individuals attend, whereas others require the attendance of as many as 25,000 people to qualify [2]. Outbreaks, however, occur irrespective of the size of a gathering and are described not only in settings such as private parties, weddings, and other events involving fewer than 1,000 attendees, but also in large MGs, such as religious MGs, attended by millions of people [3]. In addition to the number of people, MGs are events at a specific site for a definite time which may greatly vary between different MGs. These gatherings might be planned or unplanned and recurrent or sporadic.
Although large scale open air festivals have become important spring and summer activities and attract thousands of people, they are probably neglected, particularly music festivals, in terms of public health attention, as well as surveillance and prevention of infectious disease strategies, compared to other categories of MGs such as sport or religious events. Indeed, most of the literature on MGs in this respect, has addressed health issues related to very large MGs, including the Hajj [2] and the Olympic Games [4].

A characteristic of large scale open air festivals, including music festivals, may be that they are not always organised and managed by professionals and may involve inexperienced volunteers as staff members. Music festivals in particular have also specific characteristics, including outdoor settings, on-site housing and food supply, the young age of the participants, recreational motivations, and the potential for excessive alcohol or drug consumption, which may notably increase the risk of sexually transmitted infections (STIs) [5] and possibly of other infectious diseases.

A total of 858 music festivals were recorded worldwide in 2012 in choosefest database (www.choosefest.com/). The largest music festivals were in Europe where 13 of the 20 top international festivals occur (Table 1). Most festivals take place over a three to four day period with the longest lasting 11 days. Attendance for the top 20 festivals in terms of size ranges from 17,000 to 175,000 per day. According to a survey conducted in the United Kingdom (UK) during the year 2009, the total number of visits to UK music festivals was estimated to exceed 7.7 million attendees, including overseas and domestic participants combined (www.ukmusic.org/assets/media/UK\%20Music\%20 -Music\%2oTourism.pdf). Music festivals, which may involve as many as 400,000 cumulated attendees, share the usual health risks associated with large MGs, including communicable and non-communicable diseases [6-8]. A mean percentage of $1.5 \%$ attendees at music festivals seek medical care during these events, and the highest proportion recorded of attendees seeking care was $10 \%$ [9-12]. This situation may have an impact on local healthcare facilities, especially 
TABLE 1

Top 20 international music festivals by estimated attendance per day, 2012

\begin{tabular}{|c|c|c|c|}
\hline Festival & Location & Duration (days) & Estimated attendance per day \\
\hline Glastonburry & $\begin{array}{l}\text { Worthy Farm, Pilton, Shepton Mallet, Somerset, } \\
\text { United Kingdom }\end{array}$ & 5 & 175,000 \\
\hline Roskilde & Roskilde, Denmark & 4 & 110,000 \\
\hline Rock Werchter & Werchter, Belgium & 4 & 110,000 \\
\hline Rock al Parque & Bogota, Colombia & 4 & 88,600 \\
\hline T in the Park & Balado, Kinross-Shire, Scotland & 3 & 85,000 \\
\hline Summerfest & $\begin{array}{l}\text { Henry Maier Festival Park, Milwaukee, Wisconsin, } \\
\text { United States }\end{array}$ & 11 & 82,000 \\
\hline Exit & Petrovaradin Fortess, Novi Sad, Vojvodina, Serbia & 4 & 75,000 \\
\hline Coachella & Coachella, California, United States & 3 & 75,000 \\
\hline Reading-Leads Festival & Reading, Leads, United Kingdom & 3 & 75,000 \\
\hline Sziget & Budapest, Hungary & 6 & 65,000 \\
\hline Pukkelpop & Kiweit-Hasselt, Belgium & 3 & 62,500 \\
\hline Pinkpop & Landgraaf, Netherlands & 3 & 60,000 \\
\hline Big Day Out & $\begin{array}{l}\text { Gold Coast, Sydney, Melbourne, Adelaide, Perth, } \\
\text { Australia and Auckland, New Zealand } \\
\end{array}$ & 11 & 56,000 \\
\hline Burning Man & Black Rock Desert, Nevada, United States & 7 & 50,000 \\
\hline Bonnaroo & $\begin{array}{l}\text { Great Stage Park, Manchester, Tennessee, } \\
\text { United States }\end{array}$ & 4 & 40,000 \\
\hline Fuji Rock & Naebi Ski Resort, Japan & 3 & 40,000 \\
\hline Hurricane & Scheeßel, Lower Saxony, Germany & 3 & 40,000 \\
\hline Downlaod & Donington Park, United Kingdom & 3 & 37,000 \\
\hline Benicassim & $\begin{array}{l}\text { Benicassim, on the coast between Valencia and } \\
\text { Barcelona, Spain }\end{array}$ & 4 & 32,000 \\
\hline Wireless & Hyde Park, London, United Kingdom & 3 & 17,500 \\
\hline
\end{tabular}

Sources: http://www.wikifestivals.com/wiki/list-international-music-festivals-attendance, http://www.cnbc.com/id/42150834/The _ Worlds_s_Biggest_Music_Festivals, http://en.wikipedia.org/wiki/Music_festivals.

in terms of the workload on local hospitals, as found in Punchestone Racecourse, Ireland in 2004 [13]. During the Oxegen festival, which had 80,000 attendees over three days, a $45 \%$ increase in admissions to the emergency department (mainly for trauma) was observed at Nass General Hospital, with $51 \%$ of these admissions treated as inpatients. Interestingly, $47 \%$ of these patients had consumed alcohol and/or drugs [13].

A comprehensive review on outbreaks in relation to large scale open air festivals is missing. The objective of this report is to summarise the evidence related to the substantial challenges posed by communicable diseases to the organisers of large scale open air festivals, including music festivals, and outline details of infections resulting from faecal-oral, respiratory and sexual transmission. Opportunities to control these outbreaks are discussed.

\section{Methods}

Definition of large scale open air festivals Outbreaks in the setting of an open air festival, including a music festival or other art festival, village festival, cultural festival, university, religious events and large weddings were included.

Case reports and human/non-human experimental laboratory studies were excluded from the review. Outbreaks in relation with sport events, Hajj pilgrimage, food festivals, fairs or occurring in the setting of cruise ship, school, restaurant or hotel (including weddings at restaurants or hotels) were excluded because they were reviewed elsewhere [6-8].

\section{Search strategy}

To retrieve information on the transmission of infectious diseases and outbreaks during large scale open 
air festivals, we first conducted a literature search using the MEDLINE database (www.ncbi.nlm.nih.gov/ pubmed), from 1980 to July 2012, cross-referencing the following terms: 'mass gatherings', 'festivals' or 'music festivals' and 'infection' or 'infectious diseases' or 'outbreak'. Only studies published in English, but one in Serbian, were included in this review. Relevant systematic and narrative reviews were also utilised for useful background information. Subsequently, the reference lists of the systematic reviews and other identified papers were scanned for potentially relevant primary studies that could be considered for inclusion in the review. Additional search was conducted using ProMED-mail (www.promedmail.org) cross-referencing the following terms: 'festivals' or 'music' and through Google (www.google.fr) and Yahoo (fr.yahoo.com) general search-engines cross-referencing the terms: 'festivals' or 'music festivals' and 'infectious' or 'outbreak'.

\section{Results \\ Using our search strategy, 107 articles were retrieved through MEDLINE and scanning of reference lists, and 23 of these were relevant to our subject from a review of titles, abstracts, and full text of the arti- cles obtained. Pro-MED mail search allowed identify- ing only three relevant outbreaks that were already retrieved through MEDLINE. Google and Yahoo search retrieved respectively $31,900,000$ and $12,400,000$ hits, using 'festival' and 'outbreaks' terms; 6,670,000 and $11,300,000$ hits, using 'music festival' and 'outbreaks' terms and 558,000 and 200,000 hits, using 'music fes- tival' and 'infectious' terms. Given the poor relevance of search results obtained through Google and Yahoo, no further analysis was conducted using these two search-engines.}

Outbreaks and infectious diseases occurring during large scale open air festivals were classified into three categories: (i) faecal-oral transmission and gastrointestinal diseases, (ii) respiratory transmission and respiratory infections and (iii) blood-borne and sexually transmitted diseases.

\section{Faecal-oral transmission and gastrointestinal diseases}

A total of 10 outbreaks of gastrointestinal infections associated with faecal-oral transmission in the context of large scale open air festivals were retrieved and are summarised in Table 2. Of these five were linked to music festivals. Outbreaks of Cryptosporium parvum, Campylobacter, Escherichia coli, Salmonella enterica, Shigella sonnei, Staphylococcus aureus, hepatitis A virus and norovirus infections have been described over the last two decades in the United States (US), Canada, Europe and Japan and have been as well associated with events including 350 attendees, as with open air festivals involving as many as 80,000 participants. In some outbreaks, the attack rate was close to $50 \%$ of attendees, such as in Shigella outbreaks $[14,15]$ or gastroenteritis outbreaks due to norovirus [16].
Failures of hand-washing hygiene among food handlers suspected to be infected by the infectious agent lead to the contamination of food and were an important route of transmission for gastrointestinal diseases at large scale open air festivals [14,17-19]. A lack of respect for food hygiene rules has also been observed during such festivals $[17,18,20]$. Factors that contribute to gastrointestinal outbreaks at these festivals include (i) excessive production of food beyond the safe food production capacity [17], (ii) preparation of meals by a large number of volunteer food handlers $[14,18]$, and (iii) the sale of food prepared under unsanitary conditions, sometimes by vendors without a license [19-21]. Moreover, during a lunchtime concert in Cardiff, the most likely cause of the outbreak of norovirus infection was vomit contaminating inadequately cleaned and disinfected hard surfaces, carpets and soft furnishings [16].

Another important factor associated with the risk of gastrointestinal infections is the lack of adequate sanitation. Inadequate sanitation was the cause of the contamination of drinking water during the annual meeting of the Rainbow Family in the US in 1987, resulting in a large outbreak of shigellosis [15]. Inadequate sanitation associated with limited access to running water for hand washing has also been reported as the source of gastrointestinal outbreaks [14].

Unusual transmissions of gastrointestinal diseases have also occurred during large scale open air festivals. An outbreak of Escherichia coli 0157 was reported during the Glastonbury music festival in England and was linked to mud contaminated by infected cattle. Heavy rain had turned the site into a quagmire, and attendees had high levels of contaminated mud on their hands and faces [22]. Additionally, a swimming pool at an accommodation during a dance festival in Canada was identified as the source of an outbreak of diarrhoea due to Cryptosporidium parvum [23].

Overall, the estimated incidence of gastrointestinal diseases per 100,000 attendees ranged from nine to more than 55,000 during the outbreaks included in this review.

\section{Respiratory transmission and respiratory infections}

Infections acquired by respiratory routes reported in the literature in association with nine large scale open air festivals are described in Table 3. Of these, three were music festivals.

Influenza outbreaks have been reported at music festivals [24-27], with the potential for the spread of new influenza viruses in some cases $[27,28]$. In Serbia in $2009,40 \%$ of the pandemic influenza $A\left(\mathrm{H}_{1} \mathrm{~N}_{1}\right)$ pdmog cases were linked to the Exit festival [26]. Interestingly, during 2009, influenza $A\left(\mathrm{H}_{1} \mathrm{~N}_{1}\right)$ pdmog outbreaks were recorded at three of the top six music festivals ( $>100,000$ cumulated attendees) in Europe (Rock 


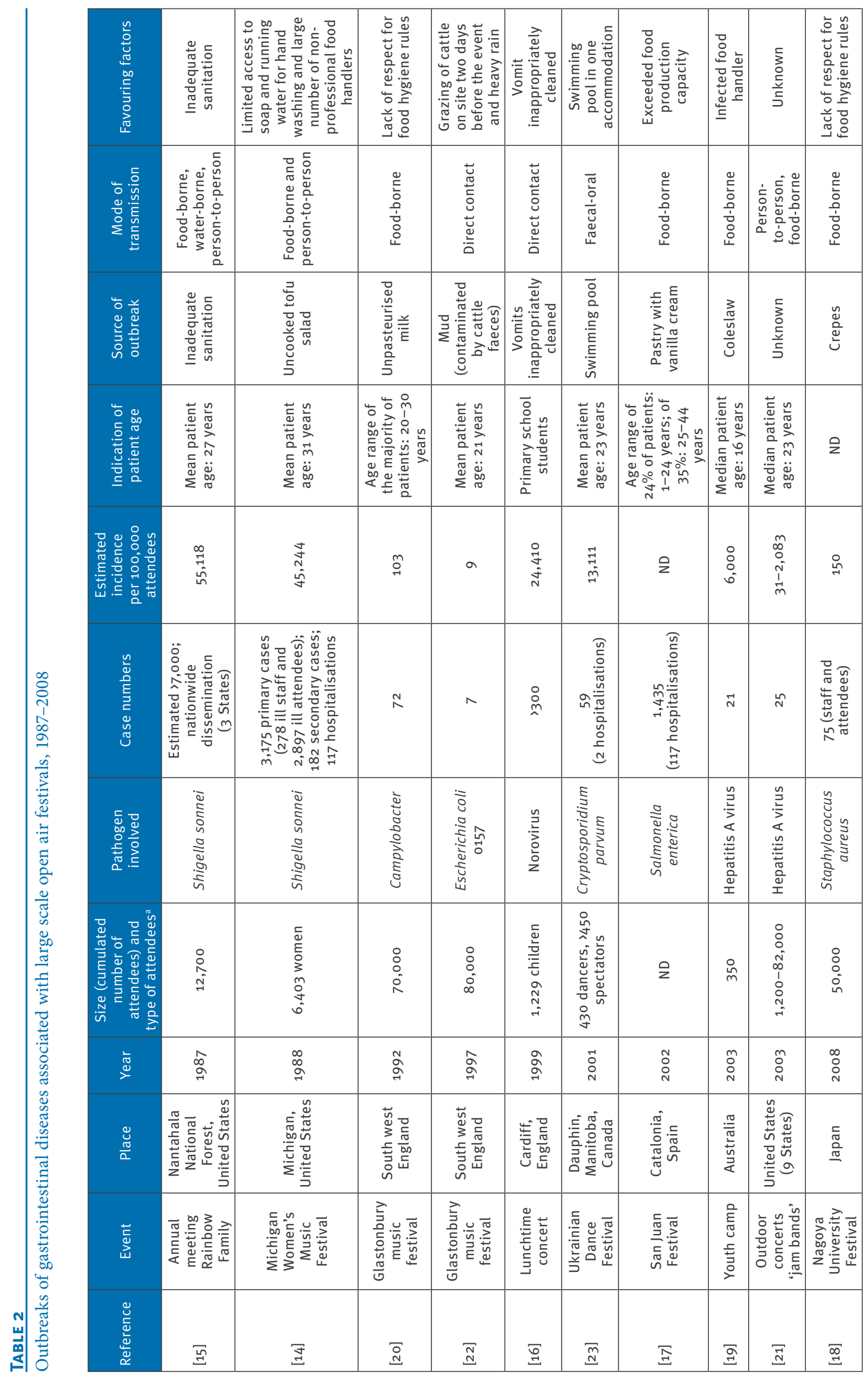




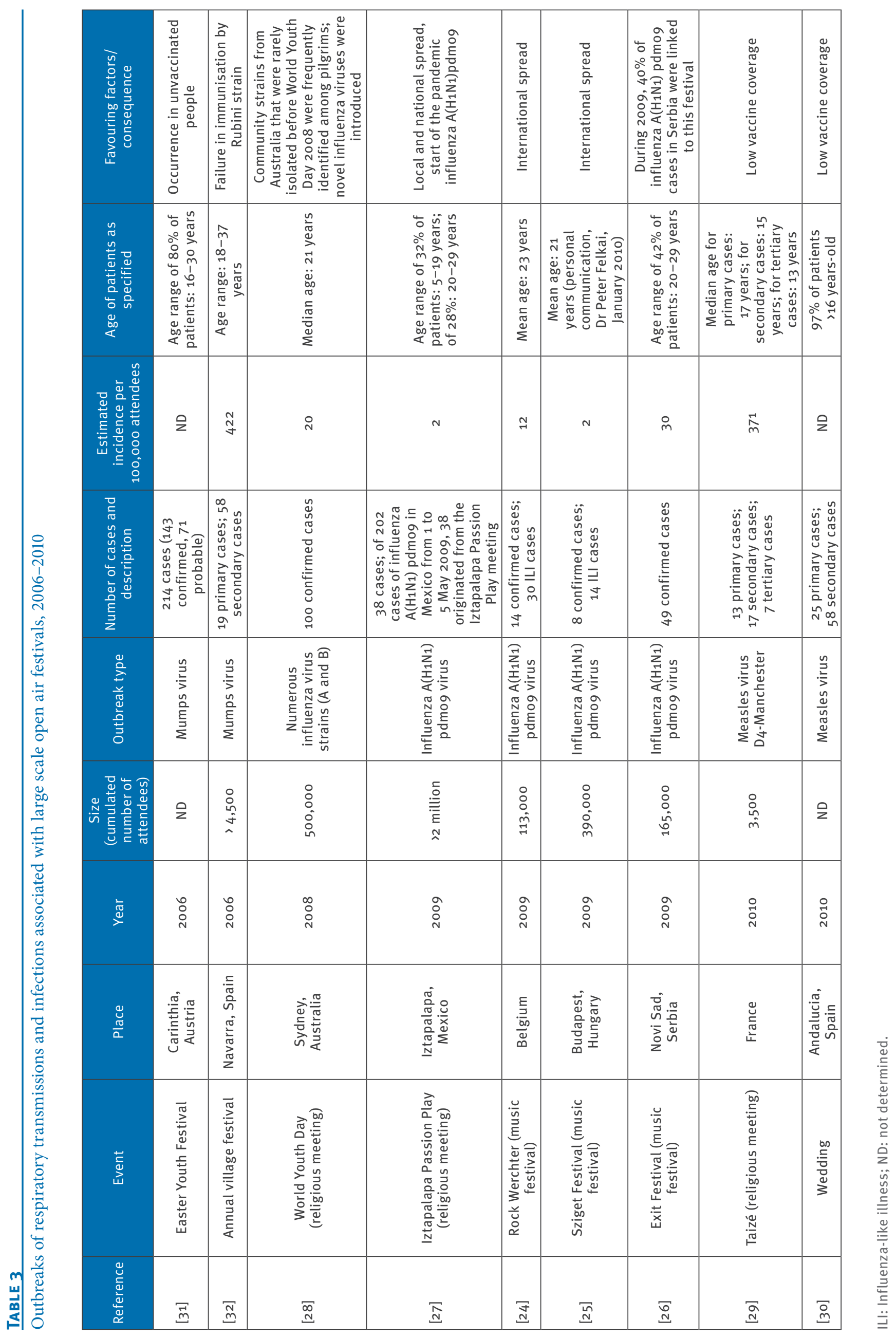


Werchter, Belgium; Sziget Festival, Hungary; and Exit Festival, Serbia).

In 2010, 13 primary measles cases were identified among unvaccinated persons aged between nine and 32 years-old in 11 districts in Germany. All cases had attended religious meetings in Taizé, France [29]. This outbreak illustrates the risk of long distance spread of infectious diseases associated with international large scale open air festivals. The same year, 25 primary cases of measles had been reported from Granada, southern Spain, of whom 22 were unvaccinated children under the age of 15 years [30]. This outbreak involved a subpopulation with low vaccination coverage and parents with ideological objections to vaccination participating to a large wedding reception [30]. Secondary cases were documented in both outbreaks.

An outbreak of mumps occurred in Austria in 2006 involving 214 individuals. Nearly half of the cases for whom vaccination status was known occurred in nonvaccinated persons, another $40 \%$ were vaccinated with one dose of vaccine. The majority of cases $(80 \%)$ occurred in persons between 16 and 30 years of age with a peak in the age group of 21 to 25 years ( $42 \%$ ). Considering the minimum incubation period of 10 to 14 days, the mumps outbreak probably originated with virus transmissions to susceptible individuals at a village Easter festival [31]. In 2006 too, a mumps outbreak including 19 primary cases was recorded in a village in Spain. Patients' ages ranged between 18 and 37 years and $94 \%$ of the patients reported attending the annual festival held in the village. 58 secondary cases were reported [32].

Overall, the estimated incidence of confirmed respiratory infections per 100,000 attendees ranged from two to more than 420 during the outbreaks included in this review.

\section{Sexual and blood transmission}

\section{of infectious diseases}

During music festivals, the risk of transmission of sexual or blood-borne infections is considered important, but this consideration is mainly speculative. Indeed, this risk is difficult to assess. Some of these infections have long incubation periods, making it difficult to relate the infection to the event. Despite the lack of evidence for the transmission of such diseases at festivals, the consumption of drugs and alcohol during music festivals is known to be high and may lead to at-risk behaviours, particularly unprotected sexual behaviours $[5,33,34]$. To our knowledge, the sexualrisk behaviour of participants during music festivals has been evaluated at several times only during the Big Day Out, one of the biggest music festivals in Australia $[33,35]$. Among sexually active participants, $43 \%$ reported not using a condom because of alcohol use [33]. Knowledge of STIs was poor overall [33]. In this young population ( $89 \%$ in the age group 16-24 years), surveillance of STI risk behaviour between 2005 and
2008 indicated that reporting having had a recent STI test increased from $23 \%$ in 2006 to $32 \%$ in 2008 [35]. Attempts to test for Chlamydia infection during the Big Day Out in 2009 has not been effective, with only $21 \%$ of participants returning the test and only one diagnosed case of Chlamydia infection [36].

\section{Discussion}

We describe various outbreaks related to large scale open air festivals, highlighting the fact that at these gatherings of people where the majority of attendees are aged 15 to 30 years, transmission of infections occurs at local, national $[15,17,21]$ and international levels $[24,25,29]$, as found during larger MGs [8]. Within open air festivals, music festivals contributed a large proportion of the outbreaks.

The outbreaks published in MEDLINE and ProMED are probably a tiny and heavily biased subset of all outbreaks associated with large scale open air festivals. This constitutes a limitation of our study and may explain the geographical repartition of the outbreaks included in our review. Unfortunately, general searchengines like Google and Yahoo are not sufficiently accurate tools to further identify outbreaks. Even the US Centers for Disease Control and Prevention foodborne outbreak online database (wwwn.cdc.gov/ foodborneoutbreaks/Default.aspx) does not allow a distinction between festivals, fairs, and other temporary or mobile services.

During large scale open air festivals, respiratory infections can easily be transmitted due to overcrowded conditions which may contribute to the spread of new influenza viruses, as reported during the 2009 pandemic $[25,26]$. The risk of transmission and of the introduction of new strains of viruses in countries hosting MGs or large scale open air festivals has been documented at such events $[8,27,28]$. Therefore, risk assessment and the establishment of preventive strategies should be implemented in preparation for large scale open air festivals, as for other MGs. Measles is one of the most contagious human diseases, with a basic reproduction number ranging from 7.7 to 15 in a susceptible population [37]. Increased numbers of cases have recently been observed in young adults, notably in Europe [38]. Therefore, it is not surprising that measles outbreaks have occurred during youth festivals $[29,30]$. Interestingly, although immunisation programmes are required for certain MGs, such as the Hajj [8], there is no immunisation recommendation for large scale open air festivals.

Outbreaks of vaccine-preventable diseases, including hepatitis $A$, influenza, measles and mumps, have been reported in connection with large scale open air festivals $[19,21,24,25,29-32]$ and could have been prevented by adequate vaccination coverage in the populations taking part. Although meningitis outbreaks have not been associated with large scale open air festivals, they have been described in the context of 
the Hajj [8]. Vaccination against meningococcus may be considered for young people planning to participate in a large scale open air festival. The use of drugs and alcohol is common at large open air festivals and may theoretically increase the risk of transmission of STIs and blood-borne diseases $[5,13,33]$.

A high incidence of Shigella, norovirus, Cryptosporidium parvum and hepatitis $A$ virus infections was found among attendees of large scale open air festivals where outbreaks were reported compared to their respective incidence in the general population, suggesting that increased transmission of gastrointestinal infections may also occur in these settings. In contrast, no evidence for substantial increased risk of outbreaks of gastrointestinal infectious diseases was found during large international sport events notably due to proper sanitary supervision of food preparation and of water sources in these events [39]. Among previous outbreaks of gastrointestinal diseases reported at large scale open air festivals, the role of inadequate sanitation has been highlighted $[14,15]$. Good sanitation is therefore critical even at the smallest gatherings, where the organisation is often non-professional. Respect for hygiene rules for food handling is also critical to avoid food-borne disease transmission. In particular, the role of volunteers in food preparation should be examined. They constitute a potential risk because they are not trained in the necessary hygiene measures [14].

The discrepancy between sport events and large scale open air festivals in terms of infectious diseases may also be the consequence of the relatively short duration of sport events which frequently last shorter than one day, with many participants moving to other locations at the end of the event and who do not live on site [39]. In contrast, large scale open air festivals last several days with most attendees staying on site during the event, sharing accommodations and sanitations. In an old study conducted in 1972, the overall incidence of communicable diseases was 75 per 100,000 attendees during a 2.5 day music festival and 580 per 100,000 during a seven day-long music festival, suggesting that the length of exposure is a contributing factor to transmission of infectious diseases in the specific setting [10].

To prevent infectious diseases, communication and on-site advice about infectious risks should be implemented and hand-washing hygiene, cough etiquette and condom use should be promoted. Reminding people before festivals to check whether they have been immunised for certain vaccine preventable diseases including measles, mumps and influenza should be promoted. To prevent STIs and blood-borne diseases, campaigns involving the free distribution of condoms and syringes for intravenous drug users may be proposed.
Finally, surveillance after large scale open air festivals with participant recall may be implemented to better address infectious disease threats of international concern at the earliest possible stages. Social networks such as Twitter or Facebook can assist with active surveillance (e.g. public health outreach on Twitter or Facebook for people reporting health related issues in the host city during a festival and for people participating in a festival). Social media can function also as a method of passive surveillance (e.g. analysis of geographically tagged tweets). Mobile phones, particularly mobile internet use, facilitate the availability of real-time information at any time and nearly anywhere in the world to the general public and may be useful in this context [4]. Surveillance could also be operated through specialised networks reporting on travelassociated diseases, including GeoSentinel [40] and EuroTravnet [41]; however participation to large scale open air festival and MGs is not documented specifically at the moment in these databases.

\section{Conclusions}

Infections related to large scale open air festivals may be under-reported given the important number of these festivals worldwide. Alternatively these could also possibly be overestimated due to 'common sense' assumptions about conditions at festivals. We assume that most outbreaks probably remain unnoticed and underreported. The relationship between infections and festivals may be difficult to establish, especially for diseases with long-incubation periods and international events, as the participants spread worldwide. Cases could have been classified under 'travel-related' infections since participation to festivals or other MGs is usually not documented in surveillance networks records. We cannot give an estimate of the frequency of communicable diseases during large scale open air festivals, because of the relative paucity of published data. The creation of an online event and patient registry should overcome this gap [42].

During an event, syndromic surveillance associated with the use of adequate laboratory facilities may help to recognise the first cases of an outbreak although the value of syndromic surveillance during MGs is highly debated [43].

Preventive measures including immunisation of people participating in large scale open air festivals and targeted on-site advice about food hygiene, hand hygiene, cough etiquette and the use of condoms may be considered. However, the effectiveness of such preventive measures in the context of MGs has not been established and research is needed before this could be recommended [44]. Finally, strict adherence to food safety protocols and adequate sanitation should be promoted to prevent gastrointestinal diseases. The presence of on-site medical staff has proven to be cost-effective in improving the medical management of injuries and other health issues, such as infections [45]. 


\section{Conflict of interest}

The authors have no conflict of interest.

\section{References}

1. McConnell J. Mass gatherings health Series. Lancet Infect Dis. 2012;12(1):8-9.

http://dx.doi.org/10.1016/S1473-3099(11)70358-9

2. Memish ZA, Stephens GM, Steffen R, Ahmed QA. Emergence of medicine for mass gatherings: lessons from the Haji. Lancet Infect Dis. 2012;12(1):56-65. http://dx.doi.org/10.1016/ S1473-3099(11)70337-1

3. Kok J, Blyth CC, Dwyer DE. Mass gatherings and the implications for the spread of infectious diseases. Future Microbiol. 2012;7(5):551-3. http://dx.doi.org/10.2217/ fmb.12.35. PMid:22568709

4. Khan K, McNabb SJ, Memish ZA, Eckhardt R, Hu W, Kossowsky $D$, et al. Infectious disease surveillance and modelling across geographic frontiers and scientific specialties. Lancet Infect Dis. 2012;12(3):222-30. http://dx.doi.org/10.1016/S1473-3099(11)70313-9

5. Hesse M, Tutenges $S$, Schliewe $S$. The use of tobacco and cannabis at an international music festival. Eur Addict Res. 2010;16(4):208-12. http://dx.doi.org/10.1159/000317250. PMid:20606446

6. Steffen R, Bouchama A, Johansson A, Dvorak J, Isla N, Smallwood C, et al. Non-communicable health risks during mass gatherings. Lancet Infect Dis. 2012;12(2):142-9. http:// dx.doi.org/10.1016/S1473-3099(11)70293-6.

7. Johansson A, Batty M, Hayashi K, Al BO, Marcozzi D, Memish ZA. Crowd and environmental management during mass gatherings. Lancet Infect Dis. 2012;12(2):150-6. http://dx.doi. org/10.1016/S1473-3099(11)70287-0.

8. Abubakar I, Gautret P, Brunette GW, Blumberg L, Johnson D, Poumerol G, et al. Global perspectives for prevention of infectious diseases associated with mass gatherings. Lancet Infect Dis. 2012;12(1):66-74. http://dx.doi.org/10.1016/ S1473-3099(11)70246-8.

9. Chapman KR, Carmichael FJ, Goode JE. Medical services for outdoor rock music festivals. Can Med Assoc J. 1982;126(8):935-8.

PMid:7074491 PMCid:1862986

10. Schlicht J, Mitcheson M, Henry M. Medical aspects of large outdoor festivals. Lancet. 1972;1(7757):948-52. http://dx.doi.org/10.1016/S0140-6736(72)91508-5

11. Levens LK, Durham JE. Pop-music festivals: some medical aspects. Br Med J. 1971;1(5742):218-20. http://dx.doi.org/10.1136/bmj.1.5742.218

12. Grange JT, Green SM, Downs W. Concert medicine: spectrum of medical problems encountered at 405 major concerts. Acad Emerg Med. 1999;6(3):202-7. http://dx.doi. org/10.1111/j.1553-2712.1999.tbo0156.x. PMid:10192671

13. Nix CM, Khan IJ, Hoban M, Little G, Keye G, O'Connor HJ. Oxegen 2004: the impact of a major music festival on the workload of a local hospital. Ir Med J. 2006;99(6):167-9. PMid:16921819

14. Lee LA, Ostroff SM, McGee HB, Johnson DR, Downes FP, Cameron DN, et al. An outbreak of shigellosis at an outdoor music festival. Am J Epidemiol. 1991;13(6)3:608-15.

15. Wharton M, Spiegel RA, Horan JM, Tauxe RV, Wells JG, Barg N, et al. A large outbreak of antibiotic-resistant shigellosis at a mass gathering. J Infect Dis. 1990;162(6):1324-8. http://dx.doi. org/10.1093/infdis/162.6.1324. PMid:2230262

16. Evans MR, Meldrum R, Lane W, Gardner D, Ribeiro CD, Gallimore $\mathrm{Cl}$, et al. An outbreak of viral gastroenteritis following environmental contamination at a concert hall. Epidemiol Infect. 2002;129(2):355-60. http://dx.doi. org/10.1017/So950268802007446. PMid:12403111 PMCid:2869894.

17. Camps N, Dominguez A, Company M, Perez M, Pardos J, Llobet T, et al. A foodborne outbreak of Salmonella infection due to overproduction of egg-containing foods for a festival. Epidemiol Infect. 2005;133(5):817-22. ttp://dx.doi.org/10.1017/ So950268805004504 PMid:16181500 PMCid:2870311.

18. Kitamoto M, Kito K, Niimi Y, Shoda S, Takamura A, Hiramatsu T, et al. Food poisoning by Staphylococcus aureus at a university festival. Jpn J Infect Dis. 2009;62(3):242-3. PMid:19468193.

19. Munnoch SA, Ashbolt RH, Coleman DJ, Walton N, Beers-Deeble MY, Taylor R. A multi-jurisdictional outbreak of hepatitis A related to a youth camp--implications for catering operations and mass gatherings. Commun Dis Intell. 2004;28(4):521-7.
20. Morgan D, Gunneberg C, Gunnell D, Healing TD, Lamerton S Soltanpoor N, et al. An outbreak of Campylobacter infection associated with the consumption of unpasteurised milk at a large festival in England. Eur J Epidemiol. 1994;10(5):581-5. http://dx.doi.org/10.1007/BF01719576. PMid:7859858

21. Centers for Disease Control and Prevention (CDC). Public health dispatch: multistate outbreak of hepatitis $A$ among young adult concert attendees--United States, 2003. MMWR Morb Mortal Wkly Rep. 2003;52(35):844-5. PMid:12966361.

22. Crampin M, Willshaw G, Hancock R, Djuretic T, Elstob C, Rouse A, et al. Outbreak of Escherichia coli $0_{157}$ infection associated with a music festival. Eur J Clin Microbiol Infect Dis. 1999;18(4):286-8. http://dx.doi.org/10.1007/s100960050278. PMid:10385018.

23. Macey J, Lior L, Johnston A, Elliott L, Krahn D, Nowicki D, et al. Outbreak of diarrheal illness in attendees at a Ukrainian dance festival, Dauphin, Manitoba--May 2001. Can Commun Dis Rep. 2002;28(17):141-5. PMid:12219577.

24. Gutiérrez I, Litzroth A, Hammadi S, Van Oyen H, Gérard C, Robesyn E, et al. Community transmission of influenza $A$ $\left(\mathrm{H}_{1} \mathrm{~N}_{1}\right) \mathrm{v}$ virus at a rock festival in Belgium, 2-5 July 2009. Euro Surveill. 2009;14(31):pii=19294. Available from: http:// www.eurosurveillance.org/ViewArticle.aspx?Articleld $=19294$. PMid:19660245.

25. Botelho-Nevers E, Gautret P, Benarous L, Charrel R, Felkai P, Parola $P$. Travel-related influenza $A / \mathrm{H}_{1} \mathrm{~N}_{1}$ infection at a rock festival in Hungary: one virus may hide another one. J Travel Med. 2010;17(3):197-8. http://dx.doi.org/10.1111/j.17088305.2010.00410.x. PMid:20536890

26. Ristic M, Seguljev Z, Nedeljkovic J, Ilic S, Injac D, Dekic J. [Importation and spread of pandemic influenza virus $A\left(\mathrm{H}_{1} \mathrm{~N}_{1}\right)$ in autonomous province of Vojvodina in preepidemic period]. Med Pregl. 2010;63(7-8):502-5. Serbian. http://dx.doi.org/10.2298/ MPNS1008502R PMid:21446138

27. Zepeda-Lopez HM, Perea-Araujo L, Miliar-Garcia A, DominguezLopez A, Xoconostle-Cazarez B, Lara-Padilla E, et al. Inside the outbreak of the 2009 influenza $A\left(\mathrm{H}_{1} \mathrm{~N}_{1}\right)$ v virus in Mexico. PLoS One. 2010;5(10):e13256.

http://dx.doi.org/10.1371/journal.pone.0013256 PMid:20949040 PMCid:2951908

28. Blyth CC, Foo H, van Hal SI, Hurt AC, Barr IG, McPhie K, et al. Influenza outbreaks during World Youth Day 2008 mass gathering. Emerg Infect Dis. 2010;16(5):809-15. http://dx.doi.org/10.3201/eid1605.091136 PMid:20409371 PMCid:2953988

29. Pfaff G, Lohr D, Santibanez S, Mankertz A, van TU, Schonberger K, et al. Spotlight on measles 2010: Measles outbreak among travellers returning from a mass gathering, Germany, September to October 2010. Euro Surveill. 2010;15(50):pii=19750. Available from: http://www. eurosurveillance.org/ViewArticle.aspx?Articleld $=19750$

30. Lopez HB, Laguna SJ, Marin R, I, Gallardo G, V, Perez ME, Mayoral Cortes JM. Spotlight on measles 2010: An ongoing outbreak of measles in an unvaccinated population in Granada,Spain, October to November 2010: an ongoing outbreak of measles in an unvaccinated population in Granada, Spain, October to November 2010. Euro Surveill 2010;15(50):pii=19746. Available from: http://www. eurosurveillance.org/ViewArticle.aspx?Articleld=19746 PMid:20738990

31. Schmid D, Holzmann H, Alfery C, Wallenko H, Popow-Kraupp $\mathrm{TH}$, Allerberger F. Mumps outbreak in young adults following a festival in Austria, 2006. Euro Surveill 2008;13(7):pii=8042. Available from: http://www.eurosurveillance.org/ViewArticle. aspx?Articleld $=8042$

32. Gerstel L, Lenglet A, Garcia CM. Mumps outbreak in young adults following a village festival in the Navarra region, Spain, August 2006. Euro Surveill 2006; 11(45):pii=3078. Available from: http://www.eurosurveillance.org/ViewArticle. aspx?Articleld $=3078$ PMid:17213550

33. Lim MS, Hellard ME, Aitken CK, Hocking JS. Sexual-risk behaviour, self-perceived risk and knowledge of sexually transmissible infections among young Australians attending a music festival. Sex Health. 2007;4(1):51-6. http://dx.doi.org/10.1071/SHo6031 PMid:17382039

34. van Gemert C, Dietze P, Gold J, Sacks-Davis R, Stoove M, Vally $\mathrm{H}$, et al. The Australian national binge drinking campaign: campaign recognition among young people at a music festival who report risky drinking. BMC Public Health. 2011;11:482. http://dx.doi.org/10.1186/1471-2458-11-482 PMid:21689457 PMCid:3148999

35. Lim MS, Hellard ME, Aitken CK, Hocking JS. Surveillance of STI risk behaviour among young people attending a music festival in Australia, 2005-08. Aust N Z J Public Health. 
2009;33(5):482-4.

http://dx.doi.org/10.1111/j.1753-6405.2009.00434.x

PMid:19811488

36. Sacks-Davis R, Gold J, Aitken CK, Hellard ME. Home-based chlamydia testing of young people attending a music festival-who will pee and post? BMC Public Health. 2010;10:376. http://dx.doi.org/10.1186/1471-2458-10-376. PMid:20584287 PMCid:2912808

37. Mossong J, Muller CP. Estimation of the basic reproduction number of measles during an outbreak in a partially vaccinated population. Epidemiol Infect. 2000;124(2):273-8. http://dx.doi. org/10.1017/S0950268899003672

38. Muscat M. Who gets measles in Europe? J Infect Dis. 2011;204 Suppl 1:S353-S365. http://dx.doi.org/10.1093/infdis/jiro67. PMid:21666185

39. Zielinski A. Evidence for excessive incidence of infectious diseases at mass gatherings with special reference to sporting events. Przegl Epidemiol. 2009;63(3):343-51. PMid:19899589

40. Freedman DO, Weld LH, Kozarsky PE, Fisk T, Robins R, von Sonnenburg F, et al. Spectrum of disease and relation to place of exposure among ill returned travelers. N Engl J Med. 2006;354(2):119-30. http://dx.doi.org/10.1056/NEJMoa051331. PMid:16407507

41. Gautret P, Schlagenhauf P, Gaudart J, Castelli F, Brouqui P, von Sonnenburg F, et al. EuroTravNet/GeoSentinel study of travel-related infectious diseases in Europe. Emerg Infect Dis. 2009;15(11):1783-90. http://dx.doi.org/10.3201/eid1511.091147. PMid:19891866 PMCid:2857260

42. Lund A, Turris SA, Amiri N, Lewis K, Carson M. Mass-Gathering Medicine: Creation of an Online Event and Patient Registry. Prehosp Disaster Med. 2012;27(6):601-11. http://dx.doi. org/10.1017/S1049023X12001367. PMid:23031486

43. Zieliński A. Enhanced surveillance at mass gatherings. Przegl Epidemiol. 2009;63(4):477-85. PMid:20120944.

44. Tam JS, Barbeschi M, Shapovalova N, Briand S, Memish ZA, Kieny MP. Research agenda for mass gatherings: a call to action. Lancet Infect Dis. 2012;12(3):231-9. http://dx.doi. org/10.1016/S1473-3099(11)70353-X.

45. Mikkelsen JB, Larsen CF. [Prehospital treatment at large outdoor music festivals. Economic aspects]. Nord Med. 1994;109(3):93-5. Danish. PMid:8139906 